\title{
MIR373 Gene
}

National Cancer Institute

\section{Source}

National Cancer Institute. MIR373 Gene. NCI Thesaurus. Code C81806.

This gene is involved in the regulation of gene expression and acts as an oncogene in breast carcinoma and testicular germ cell tumors. 